\title{
INDEPENDENT CANDIDATURE AND THE ELECTORAL PROCESS IN AFRICA
}

\author{
Churchill Ewumbue-Monono
}

Dr Churchill Ewumbue-Monono is Minister-Counsellor in the Cameroon Embassy in Russia UI Povarskaya, 40, PO Box 136, International Post, Moscow, Russian Federation

Tel: +290 65 49/2900063; Fax: +2906116

e-mail: cemonono@hotmail.com

\begin{abstract}
This study reviews the participation of independent, non-partisan candidates in Africa. It examines the development of competitive elections on the continent between 1945 and 2005, a period which includes both decolonisation and democratic transition elections. It also focuses on the participation of independent candidates in these elections at both legislative and presidential levels. It further analyses the place of independent candidature in the continent's future electoral processes.
\end{abstract}

\section{INTRODUCTION}

The concept of political independence, whether it refers to voters or to candidates, describes an individual's non-attachment to and non-identification with a political party. Generally, voter-centred political independence takes the form of independent voters who, when registering to vote, do not declare their affiliation to a political party. There are also swing or floating voters, who vote independently for personalities or issues not for parties, and switch voters, who are registered voters with a history of crossing party lines. Furthermore, candidate-centred political independence may take the form of apolitical, independent, non-partisan candidates, as well as official and unofficial party candidates (Safire 1968, p 658).

The recognition of political independence as a feature of the electoral process has led to the involvement of 'independent personalities' in managing election institutions. Examples are 'independent judiciaries', 'independent electoral commissions', and 'independent election observers'. But the issue has also been 
gaining ground because of a demand that such independent personalities should not only be confined to managing elections, but should also participate as candidates alongside those of political parties to defend the interests of the independent voters who constitute a distinct estate in the polity (Tordoff 1993, pp 91-120).

This demand stems from disappointment among many independent voters who criticise political organisations for forcing them into ideological straitjackets and promoting mechanical campaigns which sacrifice local issues (Mwalimu 2006, pp 2-7). Moreover, because of their financial, material, and organisational resources political parties, and especially ruling parties, have been accused of corruption, coercion and undue influence over their opponents and election management officials.

Political parties have also been used as tools by ethnic, regional, and religious special interests groups to promote their interests to the detriment of the integrity of candidates. Finally, the nomination procedures used by most political parties have not always been fair and transparent, and have led to popular and more representative candidates being sacrificed to ideological or expedient considerations such as gender, geographic, linguistic, and ethnic representation (Robinson 1968).

The shortcomings of party-centred elections have led to a re-examination of the role in the electoral process of independent candidates, who are perceived by most observers as the conscience of the society and the voice of the silent majority. They are also catalysts of campaign debates on the real issues affecting the electorate, which political parties and professional political consultants would like sidelined. Moreover, they are usually exempt from the dirty politics of big party machines, although they are not totally free from intrigue, which is the stock in trade of politics (Mwalimu 2006).

The practice of independent candidates is well established in both the old Western democracies and in emerging democracies. In Britain the issue rocked the political stage in May 2000 when Ken Livingstone, who was elbowed out as the Labour Party's official candidate for Mayor of London, decided to run as an independent against seven party candidates and won with 57,9 per cent of the vote against 42,08 per cent for his nearest rival.

Independent candidates also emerged as an important feature of the democratisation process in Eastern European countries. In Russia, for instance, independents have been a major political force in legislative and presidential elections organised between 1993 and 2003. During the March 2000 presidential election Vladimir Putin, who ran as one of the five independents against six partisan candidates, was elected with 52,9 per cent of the vote. In the 1993 legislative election 60 independents were elected, constituting the fourth-largest 
political force in the Duma, the Russian Parliament, after Russia's Choice (96), the Liberal Democrats (70), and the Communists (65). In the 1995 election 110 independents were elected, making them the second-largest parliamentary force after the Communists, with 157 members in the Duma, while in 1999 125 independents were elected, making them the most powerful force, followed by the Communists, with 113 members. In the December 2003 election, however, independents fell to second place, with 16 per cent of the popular vote and 74 seats as opposed to the United Russia Movement, with 222 seats (Economist 13-19 December 2003, pp 22-24). In Georgia independents won 16 seats in the 235-member Parliament, alongside seven political organisations.

The strength of independent candidates in European politics was also demonstrated in the presidential election of 22 January 2006 in Portugal in which one of the three independent candidates, Anibal Antonio Cavalo Silva, won by 50,54 per cent and was closely followed by two other independent candidates, Manuel de Melo Duarte (20,74\%), and Mario Alberto Lopes Soares (14,3\%). In effect, the total strength of the three independent candidates was about 85 per cent, as opposed to those fielded by political parties like the Portuguese Communist Party $(8,64 \%)$, the Left Block (5,32\%), and the Communist Party of Portuguese Workers.

In the United States debate about independent candidates has been a permanent feature because of the perception that most voters are independent. In his book The Power Game, published in 1988, Hedrick Smith noted that the most important phenomenon in American politics in the last quarter of the 20th century has been the increase in the numbers of independent candidates and non-partisan voters. This issue was manifested in the presidential elections of 1968, 1980, 1992, 1996, and 2004 (Wattenberg 1991).

In the 1968 election George Wallace, then Governor of Alabama, revived interest in the issue when he ran as an independent in the Nixon-Humphrey duel. In 1980 John Anderson followed suit, running as an independent against Ronald Reagan and Jimmy Carter. In 1992 business magnate Ross Perot ran as an independent candidate against Bill Clinton and George Bush and in 1996 he ran again against Bill Clinton and Bob Dole in defiance of the 'party gridlock'. In the 2000 election Ralph Nader of the Green Movement ran as an independent candidate in the George W Bush-Al Gore contest and ran again in 2004 when Bush fought John Kerry. The results of these experiences were interesting. George Wallace won 14 per cent of the total votes in 1968, while Ross Perot won 19 per cent in 1992, the largest total won by an independent in 80 years (Wattenberg 1991).

Other democracies in which independents have registered impressive performances in legislative elections in recent years include the Philippines, where 
they obtained 7 per cent of the 215-seat Parliament in the May 2001 election; Pakistan, where they obtained 21 seats in the 342-seat Parliament and 14,1 per cent of the votes polled in the October 2002 election; and India, where they obtained two of the 545 seats in the Lower House, the Lok Sabha, in the September-October 1999 election, as well as 14 of the 245 seats in the Upper House, the Rajya Sabha, in the March 2000 election. There is also great potential for the growth of independent candidates in Latin America where it is estimated that fewer than 20 per cent of the people have confidence in political parties (Posner 2006, p 20).

Independent candidature has been a universal principle in the democratisation process and has been practised in most parts of the world. Small wonder, therefore, that it has been a feature of African elections since the colonial period.

\section{THE DEVELOPMENT OF COMPETITIVE ELECTIONS IN AFRICA} 1945-2002

The development of elections in Africa has been closely linked to the existing political regimes on the continent, which Bratton and Van de Walle (1997, p 196) classified as: the military oligarchy, the plebiscitary one-party system, the competitive one-party system, and the multiparty system (Bratton \& Van de Walle 1997, p 196).

In military oligarchies elections and popular consultations are suspended and most political decisions are made behind closed doors by a few members of the elite. In the plebiscitary one-party system, there is a high degree of mass participation orchestrated from above and endorsed by one-party 'plebiscites' with turnout and affirmative votes exceeding 90 per cent. The competitive one-party system, on the other hand, allows for electoral contests among various party candidates for public office. Finally, in the multiparty system the constitution permits competition between different political organisations and even independent candidates.

From a historical perspective there have been three phases in the development of competitive elections in Africa. The first, which lasted roughly from 1955 to 1970, was marked by 'decolonisation elections' in the French- and British-controlled parts of the continent. Most of these elections, organised by the colonial authorities to mark the political transition from the colonial to the independent order, were democratic, competitive and involved many political parties. In March 1973 Portugal held 'decolonisation elections' for its overseas territories like Cape Verde, Guinea Bissau, Sao Tome, Angola, and Mozambique in accordance with the Overseas Law of 23 June 1972 (Pelissier 1973, pp 21-25). Finally, in Southern Africa the two main decolonisation elections took place in Zimbabwe in 1980 and Namibia in 1989 (Abbink \& Hesseling 2000, p 251). 
The second phase, which stretched roughly from 1970 to 1989, was marked by one-party elections which were either plebiscitary or competitive. Competitive one-party elections were introduced in Tanzania in 1965 before spreading to Kenya (1969), Uganda and Zambia (1973), Côte d'Ivoire (1980), Mali and Togo (1985), and Cameroon (1986). By 198913 African regimes - Cameroon, Central African Republic, Côte d'Ivoire, Madagascar, Mali, Malawi, Rwanda, Sao Tome and Principe, Seychelles, Sierra Leone, Tanzania, Togo, and Zambia - had introduced competitive one-party systems.

The period between 1970 and 1989 also witnessed the introduction of multiparty elections in countries such as Senegal and Mauritius (1976), Burkina Faso (1978), Ghana (1969, 1979), Uganda (1980), Nigeria (1979, 1982), Central African Republic (1980), Zimbabwe (1980, 1985), and Botswana.

By the end of 1989, there had been more than 300 plebiscitary and competitive popular consultations in 47 sub-Saharan countries, of which 106 were presidential elections, 185 direct parliamentary elections, and the rest municipal elections (Zartmann 1997, p 29).

The last wave in the development of competitive elections in Africa has been characterised by the continent's movement towards democratic transition, whose first phase stretched from 1990 to 1994, resulting in successful multiparty elections, 29 of them 'founding elections', in 38 of 47 sub-Saharan countries. The second phase of democratic transition elections took place between 1995 and 2002 and led to more than 100 national elections at presidential and legislative level, most of which were observed by international organisations including the OAU (Martin 1995, pp 6-7).

There were no independent candidates in the one-party elections between 1960 and 1989 because the ruling parties sponsored all the candidates. There were also few or no independent candidates in the post-colonial multiparty elections between 1960 and 1989 because the emphasis in most countries at that time was on reconstructing party-centered multiparty democracies, which facilitated mass mobilisation and control of dissenting opinions. However, there is abundant evidence of the participation of independent candidates in both the African 'decolonisation' and democratic transition elections at both the legislative and presidential levels.

\section{Independent candidature in African decolonisation elections} 1945-1989

Independent candidates have been involved in many decolonisation elections organised in countries like Nigeria, Rwanda, Northern Rhodesia (now Zambia), Sierra Leone, Cameroon, and Ghana, to mention but a few. 
In Nigeria, independent candidates remained an important feature of the electoral process between 1954 and 1959 when more than 300 politicians ran as independents in the various regional elections and the 1959 federal election. In the latter case there were 820 party-sponsored candidates and 133 independents, nine of whom found their way into Parliament. Most of the independent candidates in the 1959 federal election came from the Eastern region (Post 1963).

Independents also emerged as the third political force in the May 1956 legislative election for the Western Regional Assembly. Although they won no seats in the assembly, which was dominated by the Action Group (AG) and the National Congress of Nigeria and the Cameroons (NCNC), they polled 5 per cent of the total votes, ahead of other political parties such as the Nigeria Commoner's Liberal Party, the Commoner's Party, the Dynamic Party, and the Nigerian People's Party. Likewise, in the March 1957 legislative elections for the 84-seat Assembly of the Eastern Region independents won one seat and emerged as the third political force after the NCNC with 65 seats and UNIP with 5 seats and ahead of the Action Group and other smaller political organisations (Mackenzie \& Robinson 1960, pp 150-87).

In the May 1957 legislative elections in Sierra Leone some 43 independents stood alongside 75 candidates sponsored by political parties such as the Sierra Leone People's Party (SLPP), United Progressive Party (UPP), National Council of Sierra Leone (NCSL), Sierra Leone Independence Movement (SLIM), and the Labour Party, winning eleven seats and coming second to the SLPP and ahead of the other parties (Mackenzie \& Robinson 1960, pp 279-80).

In Rwanda independents made an impressive showing in the June-July 1960 local election, winning 237 votes and coming second after the Parti du Mouvement de L'Emancipation Hutu (PAMEHUTU), which won 2290 votes, and ahead of other parties, like the Association Pour la Promotion Sociale des Masses (APROSOMA), Rassemblement Democratique des Rwandais (RADER), and Union National Rwandais (UNAR) (Prunier 1995, p 51).

In the 1960-1961 Kenyan election for the 53 seats on the common roll reserved for African, Asian, and European candidates, independents also emerged as an important political force, with 10 of them nominated to contest the election. Of interest was the fact that although the major political parties such as the Kenyan African National Union (Kanu) and the Kenyan African Democratic Union (Kadu) officially fielded 30 and 18 candidates respectively, there were 23 'independent Kanu' and 18 'independent Kadu' candidates in the contest. At the end of the process the independents from the African, Asian, and European communities obtained 5,6 per cent of the vote and 9 of the 53 seats (Bennet \& Rosberg 1961, pp 210-11).

In the 1962 legislative election in Northern Rhodesia five independents 
contested the 45-seat European Upper Rolls and the 15-seat non-European Lower Rolls alongside 139 candidates fielded by political parties like the United Federal Party (UFP), the African National Congress (ANC), the United National Independence Party (Unip), the Liberal Party, the Rhodesia Republican Party (RRP), and the Barotse National Party (BNP). The independents won 337 of the votes $(1,15 \%)$ in the Upper Rolls, coming fifth after the UFP, Unip, the Liberals, and the ANC. They were ahead of the RRP, which won only 65 votes $-0,2$ per cent (Mulford 1964, pp 67-89).

In the 1965 Botswanan legislative election independents won the fifth-highest number of votes $-2,9$ per cent - though they won no seats - coming after the Bechuanaland (subsequently Botswana) Democratic Party, which won 28 of the 31 contested seats, with the Bechuanaland People's Party winning the other three.

Independents also played a prominent role in the decolonisation elections in Cameroon where, between 1953 and 1965, some 49 politicians contested as independents alongside 209 party-sponsored candidates in Anglophone Cameroon, representing more than 20 per cent of the electorate.

Table 1 shows the dynamics of the participation of independents in West Cameroon prior to the 1972 unification of the country. In the 1957 election the seven independents represented 16 per cent of the total number of contestants and polled 5,5 per cent of the total votes, coming fourth after the Kamerun National Congress (KNC), Kamerun National Democratic Party (KNDP), and Kamerun People's Party (KPP ).

Table 1

Independent Candidates in Anglophone Cameroon Elections 1953-1965

\begin{tabular}{|c|c|c|c|c|c|}
\hline $\begin{array}{c}\text { Election } \\
\text { Year }\end{array}$ & Independents & $\begin{array}{c}\text { Party } \\
\text { Candidates }\end{array}$ & $\begin{array}{c}\text { Seats won by } \\
\text { Independents }\end{array}$ & $\begin{array}{c}\text { Total Seats } \\
\text { Contested }\end{array}$ & $\begin{array}{c}\text { Votes } \\
\text { Polled }\end{array}$ \\
\hline 1953 & 1 & 28 & 1 & 13 & NA \\
\hline 1956 & 1 & 4 & 0 & 1 & NA \\
\hline 1957 & 7 & 37 & 0 & 13 & 4199 \\
\hline 1959 & 11 & 55 & 0 & 26 & 10434 \\
\hline 1961 & 26 & 78 & 2 & 37 & 27494 \\
\hline 1965 & 3 & 7 & 0 & 4 & 5188 \\
\hline Total & 49 & 209 & 3 & 94 & \\
\hline
\end{tabular}

Source: Ewumbue-Monono 2005, pp 58-89 
In the 1959 election the 11 independents represented 16,7 per cent of the contestants and polled 8 per cent of the total vote, coming after the KNDP, KNC, and KPP and ahead of the One Kamerun (OK) and National Congress of Nigeria and the Cameroons (NCNC) parties.

In the December 1961 election the 16 independents represented 25 per cent of the contestants and polled 10,7 per cent of the total vote, emerging as the third force after the KNDP and Cameroon People's National Congress (CPNC). Finally, in the 1965 by-election, the last multiparty election in Cameroon, they won 17,2 per cent of the votes polled, coming second to the KNDP and ahead of the official opposition CPNC (Ewumbue-Monono 2005, pp 55-89).

Another country in which independents won a considerable number of votes in various legislative and presidential elections was Ghana. In its decolonisation legislative election of July 1956, for instance, two independents were elected to the 104-seat Parliament. The place of the independents, however, was reduced in the August 1969 post-Nkrumah multiparty election when they won only one of the 104 seats.

Eleven independents contested the democratic legislative elections organised by the first Rawlings regime in June 1979, though none succeeded in winning a seat. Their fortunes were, however, brighter in the December 1992 legislative election when they took two of the 200 seats in the Assembly and polled 2,7 per cent of the popular vote, emerging as the third force after the National Democratic Congress (NDC) and National Convention Party (NCP) and ahead of the Every Ghanaian Living Everywhere (EGLE) group.

Finally, independents manifested themselves in the June 1979 Ghanaian presidential election when four of them, namely, Dr R P Baffour, Kwame Nyanteh, Diamomd Nii Ady, and Alhadji Imoro Ayannah, fought alongside six candidates sponsored by political parties, namely, Dr Hilla Limann (PNP), Victor Owusu (PFP), William Ofori-Atta United National Convention (UNC), Col Frank George Bernasko Action Congress Party (ACP), Alhadji Ibrahim Mahama Social Democratic Front (SDF), and Dr John Bilson Third Force Party (TFP). Although they only won 1,56 per cent of the vote their participation in the process showed that there is a high degree of political tolerance (Badu \& Larvie 1998, pp 10-29).

\section{INDEPENDENT CANDIDATES IN DEMOCRATIC TRANSITION ELECTIONS 1990-2002}

The period of democratic transition elections in Africa started with the 1990 Arusha Charter and the Declaration on the Fundamental Changes in the World of the same year in which African leaders committed themselves to promoting democratisation on the continent. As part of this commitment most African 
constitutions and electoral laws were amended to accommodate the participation of independents at legislative, presidential and even municipal levels. ${ }^{1}$

\section{Independent candidates in African democratic legislative elections 1990-2002}

A survey of 31 democratic transition legislative elections in 20 African countries between 1990 and 2002 shows that independents won only 258 seats of a total of $5829(4,4 \%)$, while 208 political parties won 5571 seats $(95,5 \%)$ (see Table 2).

It is clear from Table 2 that independent candidates performed impressively in Egypt, Madagascar, Algeria, Côte d'Ivoire, Congo Republic, Ethiopia, Zambia, Gabon, Mauritania, and the Central African Republic. Although in some of these elections the independents did not win any seats they were able to poll a considerable number of popular votes, to make them a formidable force in the democratic process in all parts of Africa.

In Southern Africa the phenomenon of independent candidature emerged in the 1993 Zimbabwean legislative election when some 16 dissatisfied Zimbabwe African National Union-Patriotic Front (Zanu-PF) members in Mavingo province fought and won as independents against the official party candidates. Their courage created a domino effect as, in the 1995 legislative election, Margaret Dongo won as an independent in Harare against the official Zanu-PF candidate. The process continued thereafter with the election of Lawrence Mudehwe, who also won as an independent in the October 1995 election for executive mayor of the city of Mutare (Nkiwane, Tandeka, and C Nkiwane, pp 103-105).

Fifteen parties contested the 2000 Zimbabwean election with Zanu-PF and the Movement for Democratic Change (MDC) fielding 120 candidates each followed by the United Parties (UP) (59), the Zimbabwe African People's Union (Zapu) (21), Zimbabwe Union of Democrats (ZUD) (16), Liberty Party (LP) (8), Liberty Party of Zimbabwe (LPZ ) (14), Zimbabwe Integrated Programme (ZIP) (4) and the rest one candidate each. However, 89 independents stood and, although they won no seats, they represented the third political force, with 51971 of popular votes polled, the next highest amount after the Zanu-PF (1 220 951), and the MDC (1 150 793) (Matlosa 2002).

In the most recent legislative election in Zimbabwe, in March 2005, 17 independent candidates stood against 253 candidates fielded by four political

\footnotetext{
See Article 10118 of the Senegalese Basic Law No 92-15 of 7 February 1992 of the Electoral Code; Article 28 of the Senegalese Constitution and Article 143 and Article 166 (7) of the Electoral Code; and Article 32 of Ordinance No 92-081 of the Burkina be Electoral Code on the principle of independent candidature during elections.
} 
Table 2

Independents in African Legislative Elections: 1990-2002

\begin{tabular}{|l|l|c|c|c|}
\hline Country & \multicolumn{1}{c|}{$\begin{array}{c}\text { Election } \\
\text { date }\end{array}$} & $\begin{array}{c}\text { Parties with } \\
\text { seats }\end{array}$ & $\begin{array}{c}\text { Seats won by } \\
\text { independents }\end{array}$ & $\begin{array}{c}\text { Total } \\
\text { seats }\end{array}$ \\
\hline Côte d'Ivoire & November 1990 & 4 & 2 & 175 \\
\hline Mauritania & March 1992 & 3 & 10 & 79 \\
\hline Congo Republic & May-June 1992 & 13 & 2 & 125 \\
\hline Congo Republic & June 1992 & 8 & 6 & 125 \\
\hline Ghana & December 1992 & 3 & 2 & 200 \\
\hline Central African Rep & Aug-September 1993 & 11 & 2 & 85 \\
\hline Ethiopia & May-June 1995 & 7 & 8 & 547 \\
\hline Zimbabwe & 1995 & 3 & 1 & 120 \\
\hline Gabon & Dec-Jan 1996-1997 & 6 & 7 & 120 \\
\hline Cameroon & June 1997 & 5 & 0 & 180 \\
\hline Comoros & December 1996 & 2 & 2 & 42 \\
\hline Mauritania & October 1996 & 3 & 7 & 79 \\
\hline Niger & November 1996 & 8 & 3 & 83 \\
\hline Zambia & November 1996 & 5 & 11 & 150 \\
\hline Gambia & January 1997 & 4 & 2 & 45 \\
\hline Malawi & June 1999 & 3 & 4 & 192 \\
\hline Ethiopia & May-August 2000 & 14 & 13 & 527 \\
\hline Zimbabwe & June 2000 & 15 & 0 & 120 \\
\hline Egypt & Oct-November 2000 & 6 & 37 & 444 \\
\hline Sudan & December 2000 & 1 & 5 & 360 \\
\hline Ghana & Dec 2000-Jan 2001 & 4 & 4 & 200 \\
\hline Côte d'Ivoire & Dec 2000- Jan 2001 & 6 & 22 & 225 \\
\hline Ethiopia & February 2001 & 13 & 8 & 548 \\
\hline Mauritania & October 2001 & 7 & - & 81 \\
\hline Zambia & December 2001 & 7 & 1 & 159 \\
\hline Gabon & December 2001 & 9 & 12 & 120 \\
\hline Algeria & May 2002 & 9 & 30 & 144 \\
\hline Congo Republic & May-June 2002 & 33 & 21 & 153 \\
\hline Mali & July 2002 & 4 & 6 & 160 \\
\hline Togo & October 2002 & 5 & 8 & 81 \\
\hline Madagascar & December 2002 & 7 & 22 & 160 \\
\hline Total & & 228 & 258 & 5829 \\
\hline
\end{tabular}

Source: Olukoshi, and Electionworld.org/Elections around the World 
parties, namely Zanu-PF (120), the MDC (120), Zanu-Ndonga (11), and Zimbabwe Youth Alliance (ZIYA) (2). Four smaller political parties - the Democratic Party (DP), Zapu, the National Alliance for Good Governance (NAGG), and the Multiracial Christian Democrats (MCD) - failed to nominate candidates in spite of their intention to run, At the end of the process, the independents emerged as the third electoral force in the country, with 0,6 per cent of the popular vote, coming after the Zanu-PF $(59,6 \%)$, and the MDC $(39,5 \%)$, and ahead of the other two parties, which won only 0,3 per cent. More importantly, Jonathan Moyo, a former Zanu-PF Central Committee member and Minister of Information, who had served as the party's campaign manager in the 2000 legislative election, contested and won the Tsholotsho Constituency against the Zanu-PF candidate, Musa Ncube-Mathema, and the incumbent MDC MP, Mtoliki Sibanda.

In the 1993 legislative election in Lesotho independents represented the fourth electoral force, with 2753 votes $(0,51 \%)$, coming after the Basutoland Congress Party (BCP), the Basotho National Party (BNP) and the Marematlou Freedom Party (MFP). Although they were not able to win a seat in the Assembly, they represented a greater electoral force than eight other parties which participated in the election, namely the Popular Front for Democracy (PFD), the Hareeng Basutho Party (HB), the United Democratic Party (UDP), the Kapanang Basutho Party (KBP), the Lesotho Labour Party (LLP), the National Independence Party (NIP), the United Democratic Party (UDP), and the Liberal Party of Lesotho (LPL) (Southall \& Petlane 1995, p 160).

In the June 1999 legislative election in Malawi independents emerged as the fourth force, with 7,1 per cent of the vote and 4 seats in the 192-seat Parliament, coming after the United Democratic Front (UDF), the Malawi Congress Party (MCP), and the Alliance for Democracy (AFORD).

In East Africa, independent candidates have played an important role in Ethiopia's democratisation process. In the May-June 1995 election 8 independents were elected to the 547-seat House of People's Representatives. In the June-August 2000 election, the number of elected independents climbed to 13. In the May 2005 general election some 353 independent candidates stood against 1845 candidates fielded by 35 political parties. Although only one independent won a seat in the Assembly the victory was of great political significance because it involved former president Dr Negaso Gidada, who had fallen out of favour with the Ethiopian People's Revolutionary Democratic Front (EPRDF) and was replaced in October 2001 by the independent parliamentarian from the Becho Constituency in West Shoa District, Girma Wolde Giorgis. In 2001, prior to Girma Wolde's election, the Ethiopian Parliament passed Proclamation 255/94, which stipulated that only independent, non-partisan parliamentarians were eligible for election to the position of President of the Republic (Ewumbue-Monono, 2005, p 21). 
In a show of popularity and political relevance, from which a comeback to the prestigious position of president of the Republic was not excluded, Negaso stood as an independent in the Dembi Dolo Constituency of the Oromia region against the EPRDF candidate, Ambassador Solomon Abebe Tessma, and another independent, Ato Befekadu Lencho Jima. Negaso won a landslide victory, with 79,96 per cent of the vote, against Tesmma (17,63\%), and Jima (2,41\%). Negaso's victory made him the only elected independent candidate in the House of People's Representatives and consequently the only one eligible to stand for president, unless he does not wish to or the rules are changed for a second time to bar him from the position (http/ / www.electionsethiopia.org/Oromia.aspx).

In Uganda the February 1989 and March 1994 legislative elections for 278 members of the National Assembly were held on a non-partisan basis within the 'no-party movement' system, which required all contestants to be essentially independent candidates. Similar 'no-party movement' elections were introduced in the Democratic Republic of the Congo by the Alliance of Democratic Forces for the Liberation of the Congo (AFDL) under Laurent Kabila in 1997 and were used in the 2000 Rwandese local government election organised by the Rwandan Patriotic Front (RPF). In the May 2000 Ethiopian legislative election, which was contested by 14 parties, independents won 13 of the 547 seats and in May 2005 353 independents stood against 1845 candidates fielded by 36 political organisations, winning only one seat.

In North Africa independents emerged as the second force in Egypt after the October-November 2000 election in which they took 37 of the 444 seats, trailing the National Democratic Party (HDW) and ahead of the 'independent HDW', New Delegation Party (HJW), Progressive National Union Party (HTWTW), Nasserist Party, and the Liberal Party (Ahrar). In the May 2002 Algerian legislative election independents emerged as the fifth force, taking 30 seats in the 380-seat Parliament, and winning 4,9 per cent of the votes, after the Front for National Liberation (FLN), National Rally for Democracy (RND), Movement for National Reform (Islah), and Movement of the Society for Peace (MSP), and ahead of the Labour Party (PT), Islamic Renaissance Movement (MRI), and Party of Algeria Renewal (PRA).

In West Africa, some 57 independents from several regions across the nation contested the September 1996 Ghanaian legislative election for the 200-seat Parliament, standing against 723 candidates sponsored by political parties. Although they won no seats, they represented 7,5 per cent of the nominations. Independents stood in Accra (16), Volta (12), Ashanti (5), B/A (7), Eastern (6), Western (2), Northern (5), U / Eastern (2), and U/West (1) (Badu \& Larvie 1998, p 39). In the December 2000 legislative election, independents re-emerged as the third force in Ghanaian politics, winning four parliamentary seats. 
In the December 2000 Ivorian legislative election, independents won 16 of the 196 seats, coming third after the FPI, which won 96 and the Parti Democratique de Côte d'Ivoire, Section du Rassemblement Democratique Africain (PDCI-RDA), with 77 seats. Moreover, there were more independents in the Parliament than representatives of parties like the Parti Ivoirien des Travailleurs (PIT), with its four seats, and the Movement of the Future Forces (MFA), the Union of Democrats of Côte d'Ivoire (UDCI), and the Rassemblement des Republicains (RDR), which won only one seat each.

Finally, independents have been able to capture seats in local councils during the continent's democratic transition. In Côte d'Ivoire, for instance, the March 2001 municipal election in 195 local councils saw independents take over 38 councils, third only to major parties like the RDR (64) and the PDCI-RDA (58). Moreover, independents performed better than other important political parties like President Gbagbo's Ivorian People's Front (FPI), which won 34 communes, and the PIT, which won only one.

In the May 2005 Ethiopian general election 70 independent candidates contested the 1920 seats of the 10 regional councils and the Addis Ababa City Council against 3662 candidates sponsored by 33 political parties. Only 13 were elected; two from the 99-member Benshangul Gumuz State Council and eleven from the 182-member Somali State Council (http: / / www.electionsethiopia.org / Results).

\section{INDEPENDENT CANDIDATES AND AFRICAN DEMOCRATIC PRESIDENTIAL ELECTIONS} 1990-2002

The growth of independent candidature during the period of democratic transition has not been limited only to local and legislative elections but has also extended to presidential elections.

In Ethiopia, where independents are referred to as 'private candidates', Parliament passed a law in 2001 stipulating that only independent, non-partisan parliamentarians are eligible for election to the position of president. Consequently, in October 2001, Girma Wolde Giorgis, an independent parliamentarian from the Becho Woreda of the West Shoa District, was elected, replacing Dr Negaso Gidada. A retired flight lieutenant, President Girma has been an active civil society leader in Ethiopia, having served as president of the Ethiopian Red Cross Society, president of the Ethiopian Writers Association, and a board member of the Ethiopian Chamber of Commerce. His re-election in 2001 as one of the eight independents in the 548-seat Parliament confirmed him as a leading force in civil society in the country and paved the way for his election as president. 
In the April-May 2002 Malian presidential election three independent candidates - Toumani Toure, Manda Sidibe, and Ahmed Diallo - stood against four candidates sponsored by political parties, namely, Soumaila Cisse of the Alliance Pour la Democratie de Mali (ADM), Ibrahim Boubacar Keita of the Rassemblement pour le Mali (RPM), Mamadou Diaby of the Parti pour L'Unité, Progres et Democratie (PUPD), and Choguel Maiga of the Mouvement Pour le Republique (MPR). At the end of the electoral process, the independent Toumani Toure emerged victorious, winning 64 per cent of the vote.

In the December 2001 Madagascan presidential election, three independents - Marc Ravalomanana, Daniel Rajakoba, and Patrick Rajaonary - stood against three partisan candidates - Didier Ratsiraka (AREMA), Albert Zafy (AFFA), and Herizo Razafimahalco (Leader-Fanilo). Ravalomanana won 51,5 per cent of the vote.

In the October 2000 Ivorian presidential election three of the five candidates - Robert Guei, Mel Theodore, and Nicolas Dioula - were independents and two represented political parties. They were Laurent Gbagbo of the Front Populaire Ivoirien (FPI) and Francis Wodie of the Parti Ivoirien des Travailleurs (PIT). Although Gbagbo won by 59,3 per cent and Wodie came third with 5,7 per cent, more than 30 per cent of the votes went to the independent candidates, with Guei winning 32,72 per cent, Mel 1,47 per cent, and Dioulo 0,76 per cent.

Between 1990 and 2005 independent candidates also participated in a dozen other presidential elections in Africa. In the March 2002 Zimbabwean presidential election, one independent (Paul Siwela) stood against four partisan candidates, namely Robert Mugabe (Zanu-PF), Morgan Tsvangirai (MDC), Wilson Kumbula Zanu-Ndonga and Shakespeare Maya (NAGG). In the March 2002 Presidential election in the DRC one independent (Jean Felix Demba Telo) stood against six partisan candidates representing the Congolese Labour Party (PCT), the Union Panafricaine pour la Democratie Sociale (UPDS), the Parti de Pauvres (PP), the Convention pour la Democratie et la Republique (CPDR), the Union Congolais des Republicain (UCR), and the Parti Republicain et Liberal (PRL) while in the Cape Verdean election of February 2001 one independent (David Hopffer Almanda) ran against candidates from the African Independence Party of Guinea and Cape Verde (PAICV), the Movement for Democracy (MPD), and the Democratic Alliance for Change (ADM).

In the October 2000 presidential elections in Guinea Bissau, two independents (Fernado Gomes and Joao Tatisa) contested the position against candidates from the African Independence Party of Guinea and Cape Verde (PAIGV), the Resistance of Guinea-Barata (RGB), the Party of Social Renewal (PRS), and the National Union for Democracy and Progress (UNDP), while in the Senegalese election of FebruaryMarch 2000 there were three independents: Serigne Fall, Cheikh Abdoulaye Dieye, 
and Mademba Sock and five partisan candidates, representing the Parti Socialiste du Senegal (PS), the Parti Democratique Senegalais (PDS), the Alliance des Forces de Progrès (AFP), the Union pour le Renouveau Democratique (URD), and the Convention des Democrates et des Patriotes (CDP).

There have also been cases where more independent candidates than party members have contested presidential elections. In Algeria, six independents and one partisan candidate contested the April 1999 election. In the Sudanese election of December 2000 and the Sao Tome presidential election of July 2001, three independents stood against two partisan candidates, while in the November 2003 Mauritanian election there were three independents (Mohamed Ould Haidalla, Ahmed Ould Daddah, and Messaoud Ould Boulkheir) and one partisan candidate (Achmed Taya of the Parti Republicain Democratique et Social) (www.electionworld.org).

In the March 2006 presidential election in Benin, a former senior official of the West African Development Bank stood as an independent candidate and won against a dozen candidates fielded by political parties. In the first round, on 4 March 2006, he emerged first with 35,8 per cent of the vote, followed by candidates like Adrien Houngbedi of the PRD (24,2\%), Bruno Assoumou of the PSD (16,2\%), Lethadi Soglo of the PRB $(8,4 \%)$, Antoine Kolawole Idji of the MAPD $(3,2 \%)$, Lazare Sehouveto of the MPAP (2\%), Severin Adjovi of the RDL-Vivoten (1,8\%), and Antoine Dayoni of the Force Espoir (1,25\%). In the run-off election of 19 March 2006, the independent, Yayi Boni, won by a landslide of 74,6 per cent against the PRD candidate, Adrien Houngbedi.

\section{INDEPENDENT CANDIDATES AND DEMOCRATISATION: PROBLEMS AND PROSPECTS}

Independent candidates, like political parties, do not emerge from a vacuum but in response to specific socio-economic realities, which traditional establishment parties cannot address. The growth of independent candidates in African legislative elections could be attributed to factors such as poorly managed generational politics, the failure of ambitious politicians to secure nominations in establishment parties, corrupt and non-transparent party procedures over nominations, inter-community rivalries, marginalisation of minorities in the nomination processes, and policy differences within parties.

Once the electoral system makes room for independent candidates some of these emotions are energised and channelled against the official party candidates and party hierarchy. In cases where they win, however, their participation might further provide the party hierarchy with an opportunity to detect political corruption, as well as to review some of its information sources and strategies. 
Such was the case during the 1953 legislative election in Southern Cameroon when S E Ncha, after being ousted as the official candidate for the Mamfe Constituency by the KNC party, of which he was a registered member, and replaced by Chief $S$ A Arrey, stood and won as an independent, to the chagrin of the KNC hierarchy (Ewumbue-Monono 2005, pp 171-180). A similar situation occurred with Margaret Dongo, the estranged Zanu-PF candidate in Harare in the 1995 Zimbabwean legislative election and with the recent show of force by the ebullient Jonathan Moyo in the 2005 Zimbabwean election. In effect, Moyo was expelled both from Zanu-PF and from the government in February as a result of differences with Joyce Mujuru, a President Mugabe loyalist who was elected second vice-president by the party. This pushed Moyo to stand as an independent and mobilise the grassroots Zanu-PF militants in his constituency to react against the decisions of the party hierarchy (Angus Reid Global Scan 31 March 2005).

In some cases, independent candidature can have a purgative effect, which may help to resolve communal conflicts, as some candidates are often satisfied just with running, addressing the 'real issues' in the society, which political parties like to avoid, and making their points, irrespective of whether or not they win.

In other cases, independent candidature helps to rehabilitate some popular and principled politicians who are perceived by the electorate as victims of internecine intrigues. For instance, by standing as independents after ideological differences within their respective parties, Dr Negaso Gidada in Ethiopia and Jonathan Moyo in Zimbabwe were able to send strong messages that they were still relevant and their political ideas had the endorsement and sympathy of the population.

The increase in the numbers of independent candidates in African presidential elections during the period of democratic transition could be further explained by the disappointment of many politicians and voters with the divisive party system. In Mali, Toumani Toure won on the platform of a 'unifier' against the more divisive partisan presidential candidates - this is the intention of the Ethiopian Constitution, which provides for the election of an independent parliamentarian as president.

Despite the advantages of independent candidature, a number of factors work against the participation of independents in many African national elections.

The first is the commonly accepted view, advanced by many scholars and politicians (especially 'Western' ones) that the proliferation of political parties is the main indicator of political liberalisation and democratisation in a country. Proponents of this view equate political pluralism with multiparty politics, and the number of registered political parties as a measure of democratisation.

Second is the enactment of laws barring independent candidates and making political parties the sole actors during elections. In Cameroon, for instance, the 
law forbids the participation of independent candidates in municipal and legislative elections, although they are free to contest presidential elections. In Ethiopia, where independent candidates are permitted, the law makes their participation secondary to that of political organisations by stressing that 'private candidates can be registered only to fill the remaining spaces if the number of candidates provided by political parties is fewer than twelve' (Proclamation No 119/95 cited in Zeleke 2005, p 25).

The case of Tanzania is an interesting example of the use of the rule of law in the debate surrounding the participation of independent candidates in the country's attempt to broaden representative democracy and citizen participation in public affairs. The 1961 and 1962 Tanganyika constitutions contain no restrictions on private candidature. However, after the union with Zanzibar, the 1965 interim constitution made party membership a qualification for election to public office; a condition upheld by the 1977 and 1985 one-party democracy constitutions as well as by the 1992 Constitution, which introduced multiparty politics. Moreover, the 1984 Election Act, amended in August 2000, restricted nominations for elections at all levels to political parties, and prohibited independent candidates.

The rule of law became a useful instrument in the clamour for the participation of independent candidates in Tanzania when, in 1993, Rev Christopher Mtikila petitioned the High Court to rule on the constitutionality of the participation of independents in national and local elections. While the court ruling was pending, the government introduced a Bill on 16 October 1994 amending the Constitution. This did not, however, stop the legal process and on 24 October 1994 Justice Lugakingira ruled that 'It shall be lawful for independent candidates along with candidates sponsored by political parties, to contest presidential, parliamentary, and local elections' (Rev Christopher Mtilikiv Attorney General 1995, p 68). This opinion was, however, not respected by the government, which amended the electoral law in August 2000 to be party-centred. In February 2005 Rev Mtikila continued his crusade, instituting another court action. In May 2005 the High Court of Tanzania ruled that 'It is true that Article 3 (of the Constitution) introduces a multiparty political system but we do not think that this is inconsistent with private candidature. Private candidature could well exist alongside multipartyism, as was indeed the case before the 1965 Interim Constitution' (Rev Christopher Mtiliki v Attorney General of Tanzania 2005, p 42). The court further ruled that the right to join or not to join a political party is as fundamental as the right to religious belief, which cannot be made a basis for standing for an elected political post. It therefore upheld the 1995 judgment and ordered the administration to put in place a legislative mechanism to regulate the activities of private candidates and give the voters the opportunity to decide 
whether or not such candidates are suitable (Rev Christopher Mtiliki v Attorney General of Tanzania 2005, p 42).

Third is the fact that there seems to be little demand from political actors, including members of civil society, for the participation of independent candidates in the electoral process. It is unlikely that most of the lawmakers in an African national assembly, who were elected on their respective party platforms, will advocate the participation of independent candidates in the electoral process. In Cameroon, as in most other African countries, the object of many civil society organisations is to participate as members of the various election management bodies and observation groups. Few of these organisations consider the participation of independent candidates an important issue in the quest for free and fair elections.

Fourth, opponents of the participation of independent candidates hold that such a system will bring disorder and indiscipline to the electoral process as it will create an 'informal sector' in politics. These critics believe that independents, unlike political parties, cannot be held accountable and morally liable for irresponsible actions. Extending eligibility to independents can therefore only create an imperfect political climate in which the risks of abuse will be very high (Ewumbue-Monono, 2005, pp 156-170).

Fifth, is the argument that the introduction of independents will create problems in election management as each independent candidate will have to choose his or her symbol, sign and colour, which will complicate the printing and distribution of material. It can also be argued that it is easier to devise a formula for funding candidates representing political parties than for independents.

It is important to bear in mind that independents constitute an exception and not the rule in an electoral process. Table 2 shows that in 31 legislative elections in 20 African countries independents won only 258 seats of a total of 5829 while 5571 seats were won by 208 parties. This represents only 4,4 per cent of the entire elected representation in the parliaments of the countries covered by the survey. In most cases, however, independents do not represent more than 3 per cent of the seats, although they emerge as electoral forces because of the votes they win.

\section{CONCLUSION AND THE WAY FORWARD}

This study has shown the evolution of competitive elections in Africa as well as the participation of independent candidates in these elections. It has also shown the opportunities and problems encountered by independent candidates in participating in competitive elections on the continent. 
To move the democratic process forward and include independent representation in elected bodies, African legislators and policy-makers should contemplate addressing issues like the harmonisation of the various electoral laws to make them more candidate-friendly, assigning special roles to non-partisan politicians, addressing the special needs of independent politicians, creating candidate-friendly electoral systems, and promoting policy coordination within the African Union (AU) and Regional Economic Communities (RECs) in relation to such systems.

\section{Harmonising electoral laws}

It would be helpful if all African countries were to follow the examples of Nigeria and Ethiopia and harmonise the laws relating to nomination processes to allow the participation of independent candidates at all levels.

In Nigeria the nomination process is voter-centred, not party-centred. In the case of the State House of Assembly elections the candidate is nominated in writing by 15 persons whose names appear in the register of voters for the constituency in which he or she intends to stand. In the case of gubernatorial elections the candidate must be nominated by 30 persons whose names appear in the register of voters for their respective wards and who come from at least two-thirds of all the local government areas in which he or she intends to stand (Ayoade 1999, $\mathrm{p}$ 30).

In Ethiopia candidates may either be nominated by a political organisation or by registered voters. In this connection, the February 1995 regulations stipulate that 'candidates may be nominated by political organisations or the concerned individuals may present themselves as private candidates'. With regard to independent candidates, the law also stipulates that a candidate is eligible if he or she 'produces the endorsement signatures of not less than 1,000 people who are certified by the local administration to be resident of the constituency of his candidature' (Government of Ethiopia 2003).

\section{Assigning special roles to independent politicians}

African legislators might also envisage enacting laws that encourage elected independent politicians to play special roles and have specific responsibilities in the country's political governance. In Ethiopia, for instance, the president, who is elected by the National Assembly, is expected to be non-partisan, and elected from among the independent members of the House, while the prime minister comes from the party with the parliamentary majority and the leader of the opposition from the second-largest parliamentary group. In the DRC independent 
politicians are considered to be a distinct political estate in the power-sharing arrangement. According to the December 2002 Pretoria Agreement, civil society provides one of the four vice-presidents, a number of Cabinet-level positions and statutory commissions, and members of the Provisional National Assembly (Dialogue Inter-Congolais 2002).

Elected independent parliamentarians and councillors may also play significant roles by participating in independent bodies such as national human rights commissions or as Speakers; positions in which neutrality, transparency and accountability are expected. Through such participation in political governance the process of building a consociational democracy based on power sharing not only among political parties, regions, and ethnic groups, but also between the political parties and civil society could be significantly enhanced.

\section{Addressing the special needs of independent politicians}

African legislators could also envisage enacting laws that empower the decentralised organs of national election management bodies by providing them with the means to enable the management of the special needs of independent candidates, such as verifying their nominations, providing proper identification and making available adequate electoral materials and financing. In the 2005 Ethiopian election, for instance, the National Electoral Board (NEBE) came up with a convenient formula for financing independent candidates alongside partisan ones (NEBE Report 2005).

In the 2005 Zimbabwean parliamentary election some of the 17 independent candidates created a Network of Independent Candidates for information sharing, the adoption of common strategies against the political party machines, and the provision of a forum for advocacy on the special needs of independent candidates during the election.

\section{Promoting policy co-ordination within the AU and the RECS}

Finally, African policy-makers could promote policy coordination within the African Union and the Regional Economic Communities on candidate-friendly electoral systems, notably the majoritarian first-past-the-post system (FPTP) used in most Anglophone countries; the parallel system used in countries like Cameroon, which gerrymander some constituencies in single-member constituencies; the two round system (TRS) used in many Francophone countries; and the block vote system used in Mauritius, which emphasises single-member constituencies (IDEA 1997). These systems need to be explained in more detail, particularly with a view to demonstrating which of them are the most candidate-friendly and why. 
African countries could promote regional policy coordination to harmonise the practice of independent candidature within the RECs. For instance, SADC's Principles for Election Management, Monitoring, and Observation, adopted in Johannesburg in November 2003, contain some candidate-centred provisions in relation to nominations and funding. Article 4(4), for instance, provides that 'the process of nomination of candidates (both independent and party candidates) should be transparent', while 'public funding should be extended to all parties and independent candidates contesting elections who can demonstrate a track record of support in the most recently held elections based for example on their share of the popular vote' (EISA 2004, p 21).

Moreover, within the AU process, African leaders endorsed the principle of independent candidature in their Durban Declaration on the Principles Governing Democratic Elections in Africa, adopted during the 38th Session of the OAU in July 2002. In this declaration African leaders committed themselves to respect the rights of all the actors in the electoral process, which include 'individuals and political parties', 'candidates and political parties', or 'citizens and political parties' (OAU 2002).

The recognition by RECs and the AU of the principle of independent candidates could therefore serve as a platform for policy coordination with respect to specific issues related to the management and financing of independents as well as the promotion of more inclusive, candidate-friendly legislation on the continent.

The AU could also sensitise member states to the need to make the electoral process more inclusive in their election observation reports. For instance, in its report on the 30 June 2002 twin legislative and municipal election in Cameroon, the report of the OAU Observer Mission regretted that the electoral laws in Cameroon 'do not permit independent candidatures and have prevented many competent members of the civil society from participating in the management of municipal and parliamentary affairs' (OAU nd).

At present, it seems, a lot needs to be done by the AU and the RECs to mainstream independent candidature in African democratic elections. It is unfortunate that in spite of the recognition in the OAU Declaration on the Principles Governing Democratic Elections in Africa of the principle of independent candidature the prevailing thinking among African policy-makers tends towards a narrow interpretation of pluralistic, competitive and democratic elections as those which include many political parties. This interpretation emerged during the All African Conference on Elections, Democracy and Governance in Pretoria on 7-11 April 2003 in which no mention was made of independent candidature as a principle in pluralistic elections (AU-IEC 2003).

The narrow, party-centred interpretation of pluralistic and democratic 
election on the continent by no means guarantees the sustainability of democracy in Africa. This situation stems from the emergence of dominant ruling parties on the one hand and weak opposition parties on the other, which tends to make multiparty elections mere rituals, similar to one-party plebiscitary elections. In the absence of independent candidates most dominant parties will continue to take the majority of the seats in legislative elections, largely because most opposition parties are regional and do not have the capacity to contest all constituencies. More importantly, the absence of independent candidates will reduce voters who are politically independent and non-partisan to captives of political parties. In Cameroon, for instance, it was reported that the 188 registered political parties have fewer than two million registered members, which is less than one-third of the total voting population. However, during elections, these non-partisan voters are forced to choose only among contending political parties, some of which do not present candidates of quality who can represent the people adequately (Dinga Pefok 2006).

During recent post-democratic transition elections (2002-2005) the prevailing trend has been a decline in public confidence in the role of political parties in the electoral process, especially in presidential elections, as has been demonstrated by the election of presidents Marc Ravalomanana in Madagascar, Toumani Toure in Mali, and Yayi Boni in Benin (Mwalimu 2006, p 6).

Apart from making elections more competitive and representative independent candidates can also enhance the democratisation process in most African countries. They can provide political parties with more resourceful candidates for future elections and can, equally, provide opportunities for persons whose talents cannot be channelled through political parties to participate in the county's political development.

The case of Fon Angwafor III of Cameroon is very important. Realising that the leading political parties could not field him as a candidate in the 1960s, he opted to contest the December 1961 Parliamentary election in the Bamenda constituency as an independent. He won the election and, as a parliamentarian, party leader, and local government leader, has been able to contribute enormously to Cameroon's political development. He served as deputy speaker in the West Cameroon House of Assembly between 1968 and 1972 and as a member of the National Assembly between 1973 and 1988, sitting on the influential Constitutional Committee. In 1966, when the one-party system was introduced, he was elected President of the Mezam Section of the Cameroon National Union (CNU) and in 1990 he was elected First National Vice-President of the ruling Cameroon People's Democratic Movement. As a local government leader he also served as chair of the Ngemba Council between 1962 and 1977 and of the Bamenda Urban Council between 1977 and 1996. 
Had Fon Angwafor III not had the opportunity to stand as an independent candidate Cameroon would not have benefited from his immense political experience and wisdom. There are many talented political figures like him in Cameroon and, more generally, in Africa today who, given the opportunity to stand as independents, will eventually contribute in the political development of their countries, if not of the entire continent.

\section{- REFERENCES —}

\section{Publications}

Abbink, Jon \& Gerti Hesseling. 2000. Election Observation and Democratization in Africa. New York: St Martin Press.

Abraham, Paul A. 1976. 'Generational Change and the Decline of Party Identification in America: 1952-1974'. American Political Science Review 70. Adrian, Charles. 1952. 'Some General Characteristics of Non-partisan Elections'. American Political Science Review 46, September.

Angus Reid Global Scan. 31 March 2005.

AU-IEC. 2003. Strengthening African Initiatives. Report of the Africa Conference on Election, Democracy, and Governance, Pretoria, 7-10 April.

Ayoade, J A A (ed). 1999. Handbook of Election Monitoring in Nigeria. Ibadan: Vantage Publishers.

Badu, K A \& John Larvie. 1998. Election 96 in Ghana. Part 1. Accra: GNEC.

Bennet, George \& Carl Rosberg. 1961. The Kenyatta Election. Kenya 1960-1961. Oxford: Oxford University Press.

Bratton, Michael \& Nicolas Van de Walle. 1997. Democratic Experiments in Africa. New York: Cambridge University Press.

Commonwealth Secretariat. 2001. Elections in Zanzibar, United Republic of Tanzania, 29 October 2000. The Report of the Commonwealth Observer Group. London: Commonwealth Secretariat.

Dialogue Inter-Congolais. 2002. Accord Global et Inclusif sur la transition en Republique Democratique du Congo, Pretoria, 16 December.

Dinga Pefok, Joe. 2006. 'UPC-Mackit Calls for Independent Candidatures'. The Post, 23 June.

Economist, The. 2003. 'The Russian Elections: Putin's Way', 13-19 December.

EISA. 2004. The Principles for Election Management, Monitoring, and Observation in the SADC Region. Johannesburg: EISA.

Eldersweld, Samuel J. 1952. 'The Independent Vote: Measurement, Characteristics and Implications for Party Strategy'. American Political Science Review 46.

Ewumbue-Monono. nd. Local Authorities in Communes. Political Change and the Development of Local Government in Anglophone Cameroon. Buea: CEREDDA. 
- 2001. Indigenous Minorities And Good Governance in Cameroon. An Inquiry into the Politics of Local Governance in the Local Councils of Fako Division. 18862001. Buea: CRREDDA.

- 2005. Men of Courage. The Participation of Independent and Civil Society Candidates in the Electoral Process in Cameroon. A Historical Perspective, 19452004. Buea: CEREDDA.

IDEA. 1997. The International IDEA Handbook of Electoral System Design. Stockholm: IDEA.

Henning, Melber. 2002. Zimbabwe's Presidential Elections 2002. Evidence, Lessons, and Implications. Discussion Paper 14. Uppsala: Nordic Institute for African Affairs.

Government of Ethiopia. 2003. Compendium of Electoral Legislations on Free and Fair Elections in Ethiopia. Addis Ababa: NEBE.

Greenstein, Fred. 1970. The American Party System and the American People. New Jersey: Prentice-Hall, Inc.

Keith, B, E et al. 1992. The Myth of the Independent Voter. Berkeley: University of California Press.

Kimberling, William C. 1989. The Primary Functions of an Election System.

Kontchou, K A \& Ngandjui, N. 1988. Partis et Enjeux Politiques au Cameroun (19401988). Universite de Yaoundé.

Lekene Donfack, E C. 2000. ‘La Candidature independante et la liberté de souffrage en droit camerounais'. Revue Africaine des Science Juridique 1(1).

Mackenzie, W J M \& K Robinson. 1960. Five Elections in Africa. Oxford University Press.

Martin, Guy. 1995. 'Democratic Transition in Africa'. Issues 21.

Matlosa, Khabele. 2002. 'Election Monitoring and Observation in Zimbabwe. Hegemony versus Sovereignty'. African Journal of Political Science 17(1), June.

Monono, Absalom W. 2001. 'The Opposition in Anglophone Cameroon'. Master's dissertation, University of Buea.

Mulford, David. 1964. The Northern Rhodesia General Election 1962. Oxford University Press.

Mwalimu, George Ngwane. 2006. 'Participation of Independent Candidates in the Electoral Process in Cameroon'. Memorandum presented to H E Paul Biya, President of the Republic of Cameroon by the Committee for the Participation of Independent Candidates in Cameroonian Elections, 25 March.

NEBE. 2005. Report on the 2005 General Elections. In http:// www. electionsethiopia.org

Ngoh, Julius Victor. 1986. Constitutional Development in Southern Cameroons. 19461960. Victoria. 
Ngware, S, L Dzimbiri \& R Ocharo (eds). 2000. Multipartism and People's Participation. Dar es Salaam: Tema Publishers.

Nkiwane,Tandeka \& C Nkiwane. 1998. 'Opposition Politics in Zimbabwe: The Struggle Within the Struggle'. In A Olukoshi (ed). The Politics of Opposition in Contemporary Africa. Uppsala: Nordic Afrika Institute.

OAU. 2002. OAU Declaration on the Principles Governing Democratic Elections in Africa, Durban, 8 July.

. nd. Rapport de L'Equipe d'Observation de L'OUA Aux Elections Legislatives et Municipales du 30 Juin au Cameroun. Addis Ababa: OAU.

Olukoshi, Adebayo (ed). 1998. The Politics of Opposition in Contemporary Africa. Uppsala: Nordic Afrika Institute.

Pelissier, René. 1973. 'Afrique Portugaise: Les Elections Legislative'. Revue française d'études politiques africaines 88, April.

Posner, Paul W. 2006. 'Party-Society Linkage and the Quality of Democracy'. Democracy at Large 2(3).

Post, K W J. 1963. The Nigerian Federal Election of 1959. Oxford: Oxford University Press.

Prunier, G. 1995. The Rwanda Crisis. History of a Genocide. Kampala: Fountain Publishers.

Robinson, John et al. 1968. Measures of Political Attitudes. Ann Arbor: Survey Research Center Institute of Social Research.

Safire, William. 1968. The New Language of Politics: A Dictionary of Catchwords, Slogans, and Political Usage. New York: Collier Books.

Sindjoun, Luc. 1994. 'Construction et Deconstruction Locales de L'Ordre Politique $\mathrm{Au}$ Cameroun. La Sociogenese de L'Etat'. Doctoral thesis, University of Yaoundé.

Southall, R and T Petlane (eds). 1995. Democratisation and Demilitarization in Lesotho: The General Election of 1993 and its Aftermath. Uppsala: NIAA.

Tordoff, William. 1993. Government and Politics in Africa. London: Macmillan.

Wattenberg, Martin. 1991. The Rise of Candidate-centered Politics: Presidential Elections in the 1980s. Cambridge, MA: Harvard University Press.

1994. The Decline of American Political Parties. 1952-1992. Cambridge MA: Harvard University Press.

Zartmann, W. 1997. Governance as Conflict Management: Politics and Violence in West Africa. Washington, DC: Brookings Institution.

Zeleke, Tigist. 2005. The Political Participation of Women in Ethiopia: Challenges and Prospects. Addis Ababa, EWLA. 


\section{Websites}

www.electionsethiopia.org/Oromia.aspx accessed on 17/5/2006

www.electionsethiopia.org/Results accessed on 17/5/2006

\section{Court proceedings}

Rev. Christopher Mtiliki vs Attorney General of Tanzania. 1995.

Rev. Christopher Mtiliki vs Attorney General of Tanzania. Misc Civil Case No 10 of 2005. 